PACS 61.43.-j; 67.30.hp; 71.20.-b; 71.23.-k; 73.20.At; 73.63.-b

Ya.V. Zaulychnyy ${ }^{1}$, V.Ya. Ilkiv ${ }^{1}$, V.I. Zarko ${ }^{2}$, M.V. Karpetz ${ }^{3}$, M.V. Pereginiak ${ }^{1}$, S.S. Petrovska ${ }^{3}$, V.M. Gun'ko ${ }^{2}$

\title{
MORPHOLOGICAL AND ELECTRONIC CHARACTERISTICS OF NANOALUMINA ALONE AND IN HIGH-TEMPERATURE (FUMED) AND LOW-TEMPERATURE (MECHANICAL) MIXTURES WITH NANOSILICA
}

\author{
${ }^{1}$ National Technical University of Ukraine «Kyiv Polytechnic Institute» \\ 35 Politekhnichna Str., Kyiv, 03056, Ukraine \\ ${ }^{2}$ Chuiko Institute of Surface Chemistry of National Academy of Sciences of Ukraine \\ 17 General Naumov Str., Kyiv, 03164,Ukraine, E-mail: vlad_gunko@ ukr.net \\ ${ }^{3}$ Frantsevich Institute for Problems of Materials Science of National Academy of Sciences of Ukraine \\ 3 Krzhyzhanivsky Str., Kyiv, 03680, Ukraine
}

Crystalline and electronic structures of nanoalumina alone and in different mixtures with nanosilica have been analyzed using X-ray diffraction (XRD) and ultrasoft X-ray emission spectroscopy (USXES). Narrowing of the $O K_{\alpha}$ bands of crystalline alumina occurs with decreasing nanoparticle size. Electron transfer from oxygen to aluminum atoms due to $\mathrm{Al}-\mathrm{O}$ bond breakage under irradiation leads to occupation of high-energy $3 \mathrm{~d}$ level of $\mathrm{Al}$. In nanoparticles, the $\mathrm{Al}-\mathrm{O}$ bond strength and $\mathrm{O}-\mathrm{O}$ interactions enhanced by Laplace (bubble) pressure lead to $\delta$ phase stabilizing if coherent-scattering region size $\left(d_{C S R}\right)$ reaches $7 \mathrm{~nm}$ which is smaller than that for $\theta$ phase $\left(d_{C S R}=11-20 \mathrm{~nm}\right)$ of alumina and silica/alumina studied. The $d_{C S R}$ values are in agreement with nanoparticle sizes calculated using self-consistent regularization method applied to nitrogen adsorption data.

Keywords: nanoalumina, nanosilica, electronic structure, ultrasoft X-ray emission spectroscopy, $X$-ray diffraction

\section{INTRODUCTION}

Adsorption, photocatalytic, photoelectric, photodestructive, and other properties of nanooxides are effectively used in different fields from medicine to solar power engineering [1-10]. A relatively great contribution of surface atoms of nanomaterials into the free energy and, therefore, into the interfacial phenomena affects changes in inherent properties of nanoparticles and can stabilize crystalline phases unstable in macroparticles [1]. Interatomic interactions provided by valence electrons play a primary role in these properties and interfacial processes. Investigations of energy distribution of valence electrons in different crystalline and amorphous nanomaterials [11-13] characterized by a variety of chemical bonds from covalent to ionic showed the energy redistribution of valence electrons due to diminution of particle toward nanosizes. These effects depend also on crystal structure and charge state of surface atoms.
Alumina can be in $\alpha, \beta, \gamma, \delta, \sigma, \rho, \chi, \eta$ and $\theta$ modifications. However, only $\alpha$ and $\gamma$ phases are considered as independent and stable phases, since other phases are unstable without special admixtures or a phase mixture $[14,15]$. Nanoalumina does not change the structure and grain size [16] after annealing at $600-800 \mathrm{~K}$. One can assume that high Laplace pressure [17] due to relaxation processes characteristic for nanoparticles can stabilize different alumina phases in nanoparticles. Therefore, it is of importance to elucidate a role of the electronic structure and the electronic-structural mechanism of stabilization of the mentioned phases of nanostructured alumina. The energy distribution of valence $p$-electrons of oxygen and $s d$-electrons of $\mathrm{Al}$ represents $\mathrm{O} K_{\alpha}$ and $\mathrm{Al} L_{\alpha}$ emission bands (electronic transitions $\mathrm{O} p \rightarrow \mathrm{O} 1 s$ and $\mathrm{Al} s d \rightarrow \mathrm{Al} 2 p_{2 / 3}, \quad$ respectively). Analysis of these bands for coarse-grained and nanosized aluminas can give information on the 
size effects on the electronic structure of these solids.

X-ray emission spectra showed [14] that if alumina represents a nanosized $\gamma$ phase, a high-energy maximum of the $\mathrm{Al} L_{\alpha}$ emission band decreases due to decreasing contribution of the Ald states, according to calculations of partial state density of the $\alpha$ and $\gamma$ phases. However, the $\mathrm{O} K_{\alpha}$ bands of these phases are less different. Since the differences of a variety of the alumina phases are rather essential, the aim of the present work is to study the dependence of the valence electron energy distribution on size of nanoparticles of different alumina phases, particularly the $\theta$ and $\delta$ phases, as well as the effects of nanosilica in different mixtures with alumina. Notice that ultrasoft X-ray emission spectroscopy (USXES) was successfully applied to different solid matters [18-22]. Therefore, this method was used here to analyze the size effects on the electronic structure of such fumed oxides as alumina, silica, and alumina/silica.

\section{MATERIALS AND METHODS}

Materials. Nanooxides (pilot plant of the Chuiko Institute of Surface Chemistry, Kalush, Ukraine) were synthesized using $\mathrm{SiCl}_{4}$ and $\mathrm{AlCl}_{3}$ as precursors burned in the $\mathrm{O}_{2} / \mathrm{H}_{2}$ flame resulting in hydrolysis/oxidation and formation of nanoparticles of individual fumed silica (A-300, $S_{\mathrm{BET}}=330 \mathrm{~m}^{2} / \mathrm{g}$ ) and alumina and related binary oxides (Table).

Table. Phase composition, specific surface area $\left(S_{\mathrm{BET}}\right)$, coherent-scattering region size $\left(d_{\mathrm{CSR}}\right)$ of nanoparticles and half-width $(\Delta E)$ of the $\mathrm{O} K_{\alpha}$ band of nanooxides

\begin{tabular}{lccccccc}
\hline \multicolumn{1}{c}{ Sample } & $\begin{array}{c}\mathbf{A l}_{\mathbf{2}} \mathbf{O}_{\mathbf{3}}, \\
\mathbf{w t .} \%\end{array}$ & $\begin{array}{c}\mathbf{S i O}_{\mathbf{2}}, \\
\mathbf{w t .} \%\end{array}$ & $\begin{array}{c}\mathbf{A l}_{\mathbf{2}} \mathbf{O}_{\mathbf{3}} \text { phase } \\
\text { composition }\end{array}$ & $\begin{array}{c}\boldsymbol{S}_{\text {BET }}, \\
\mathbf{m}^{2} / \mathbf{g}\end{array}$ & $\begin{array}{c}\boldsymbol{d}_{\mathbf{C S R},} \\
\mathbf{n m}\end{array}$ & $\begin{array}{c}\boldsymbol{\Delta} \boldsymbol{E}, \\
\mathbf{e V}\end{array}$ & Note \\
\hline f89 & 100 & 0 & $\theta$ & 89 & 17 & 3.8 & fumed \\
f89m & 100 & 0 & $\theta$ & & 13 & 3.4 & f89, MCA \\
sa96f & 96 & 4 & $\theta$ & 81 & 20 & 4.4 & fumed \\
sa96m & 96 & 4 & $\theta+5 \%$ am. ph. & & 11 & 3.5 & f89+A-300, MCA \\
f140 & 100 & 0 & $\delta+20 \%$ am. ph. & 140 & 7 & 3.3 & fumed \\
\hline
\end{tabular}

Note. Samples $\mathrm{f} 89 \mathrm{~m}$ and sa96m were prepared by mechanochemical activation (MCA) of f89 alone (f89m) or in a mixture with 96 wt. \% f89 + 4 wt. \% A-300 (sa96m) in a microbreaker for 5 min; and am.ph. is the amorphous phase

X-ray diffraction (XRD) investigation was carried out using monochromatic $\mathrm{Cu} K_{\alpha}$ radiation (graphite monocrystal as a monochromator) with a DRON-UM1 diffractometer (Burevestnik, St.-Petersburg, Russia) over the $2 \theta=10-90^{\circ}$ range. The XRD patterns were treated using the Powder Cell 2.4 program (ftp://ftp.bam.de/Powder_Cell/pcw23.exe). Analysis of diffraction maxima broadening connected with coherent-scattering region (CSR) sizes (which can be considered as the average size of crystallites) and lattice strain was carried out using the Williamson-Hall method. The crystallinity was determined by normalization of integral intensity of amorphous halo of studied samples to intensity of amorphous halo of completely amorphous matter. For full-profile analysis of XRD patterns, the sample morphology was taken into account using the March-Dollase model [23]. Adjustment of intensity of any $h \mathrm{kl}$ maximum was realized by introduction of effective repetition multiplier $M_{h k l}$ :

$$
M_{h k l}=\sum_{i=1}^{m}\left(\tau^{2} \cos ^{2} \varphi_{i}+\tau^{-1} \sin ^{2} \varphi_{i}\right)^{-3 / 2}
$$

where $\tau$ is adjustable texture coefficient, $m$ is crystallographic repetition multiplier of present family of equivalent planes $\{h k l\}, \varphi$ is the smallest value of angle between normal to $(h k l)_{\text {i }}$ plane and given texture vector. According to Eq. (1), $\tau=1$ when texture is absent, $M_{h k l}>1$ when $0<\tau<1$, and intensity of $h \mathrm{kl}$ maximum becomes greater than that of randomly orientated sample and $M_{h k}<1$ when $\tau>1$.

USXE spectra were recorded using a RSM-500 (SCBXA, Burevestnik, St.-Petersburg, Russia) X-ray spectrometer-monochromator with energy of electron beam $E=5 \mathrm{keV}$ and intensity $I=6 \times 10^{17}$ electron $\cdot \mathrm{cm}^{-2}$. Emission $\mathrm{Al} L_{a}$ and $\mathrm{O} K_{a}$ bands (which correspond to distribution of valence electrons of $\mathrm{Al}$ and $\mathrm{O}$ atoms) in $\mathrm{f89}$, f89m, sa96f, sa96m, and f140 samples were analyzed using the 
USXES method in respect to changes in electronic structure of the valence band of different nanosized aluminas. The photon energy distribution functions in the $\mathrm{O} K_{\alpha}$ emission bands correspond to transition of valence $\mathrm{O} 2 p$ electrons to vacant $\mathrm{O} 1 s$ levels with energy of emitted photons $h v=E_{O_{2 p}}-E_{O_{1 s}}$. According to selection rule, $\mathrm{Al} L_{\alpha}\left(\mathrm{Al} L_{23}\right)$ emission band corresponds to photon energy $h v=E_{A l_{3 s 3 d}}-E_{A l_{2 p_{1 s}}}$ due to transition of valence electrons $\mathrm{Al} 3 s$ (and $\mathrm{A} 13 d$ ) to vacant levels $\mathrm{Al} 2 p$. Vacancies in core levels are formed under action of the electron beam.

The excitation mode used does not lead to the formation of radiation defects in the materials since these defects appear only at $I>5 \times 10^{20}$ electron per $\mathrm{cm}^{-2}$. Residual pressure in an X-ray tube and a spectrometer detector was $2.67 \times 10^{-4} \mathrm{~N} \cdot \mathrm{m}^{-2}$. Samples were rubbed into copper anode (etched and rinsed in ethanol and side cooled by running water) to prevent aluminum bond breakage, oxygen thermodesorption and sintering of alumina nanoparticles during measurements. The anode adjacent to a sample was cleaned as explained above. Intensity of X-ray quanta in energy region $h v=510-535 \mathrm{eV}$ corresponding to $\mathrm{OK}_{\alpha}$ band was measured to persuade in absence of overlapping $\mathrm{OK}_{\alpha}$ bands of $\mathrm{CuO}$ and alumina. Such measurements before and after samples investigations showed that intensity of quanta generated by copper anode in mentioned energy region did not exceed background intensity.

Intensity of slope of low-energy part of the $\mathrm{O} K_{\alpha}$ bands was decreased during three spectra records with maintenance of their peak intensity. Therefore, it was investigated to prevent overlapping $\mathrm{O} K_{\alpha}$ bands of adsorbed oxygen and oxygen in nanosized alumina at different intensity of electron beam $\left(1.5 \times 10^{17}, 3 \times 10^{17}, 4.5 \times 10^{17}\right.$ and $6.0 \times 10^{17}$ electron $\left.\cdot \mathrm{cm}^{-2}\right)$.

After four records at beam intensity of $1.5 \times 10^{17}$ electron $\cdot \mathrm{cm}^{-2}$, the shape and half-width of the $\mathrm{OK}_{\alpha}$ band stabilized and did not change subsequently. Stabilization of the energy spectrum shape was revealed with increasing beam intensity during short time of irradiation. Stabilized $\mathrm{O} K_{\alpha}$ bands exited at different intensities of electron beam were similar. Stabilization of the $\mathrm{O} K_{\alpha}$ bands shape is due to removal of adsorbed oxygen and $\mathrm{H}_{2} \mathrm{O}$ from the alumina surface. It is important that the $\mathrm{O} K_{\alpha}$ band shape and the $I_{\max }\left(\mathrm{O} K_{\alpha}\right) / I_{\text {background }}$ ratio do not change with increasing intensity of electron beam from $6 \times 10^{17}$ to $15 \times 10^{17}$ electron $\cdot \mathrm{cm}^{-2}$. In beam focus, samples radiate white local temperature increases to $1570 \mathrm{~K}$ or higher with increasing intensity of electron beam to $22 \times 10^{17}$ electron $\cdot \mathrm{cm}^{-2}$. Under these conditions, the $I_{\max }\left(\mathrm{O} K_{\alpha}\right) / I_{\text {background }}$ ratio decreases due to oxygen loss from the surface layer of alumina. Changes in surroundings of certain aluminum atoms due to removal of oxygen atoms lead to changes in the $\mathrm{Al} L_{\alpha}$ band shape with changes in low-energy and high-energy components of the spectra. These results allowed us to choose optimal intensity of electron beam of $6 \times 10^{17}$ electron $\cdot \mathrm{cm}^{-2}$.

Diffraction grating with groove density $600 \mathrm{~mm}^{-1}$ and curvature radius $6 \mathrm{~m}\left(\mathrm{O} K_{a}\right)$ and $2 \mathrm{~m}$ $\left(\mathrm{Al} L_{\alpha}\right)$ was used. Instrumental distortions were smaller than 0.2 and $0.3 \mathrm{eV}$ for $\mathrm{Al} L_{\alpha}$ and $\mathrm{O} K_{\alpha}$ and accuracy of spectra recording was $0.1 \mathrm{eV}$. X-ray photons were registered using a KBL1505 (Dr. Sjuts Optotechnik GmbH, Germany) electron multiplier.

To analyze the structural characteristics of oxides, low-temperature $(77.4 \mathrm{~K})$ nitrogen adsorption-desorption isotherms were recorded using a Micromeritics ASAP 2405N adsorption analyzer or a Quantachrome Autosorb adsorption analyzer. The specific surface area $\left(S_{\mathrm{BET}}\right)$ was calculated according to the standard BET method [24]. The total pore volume $V_{\mathrm{p}}$ was evaluated from the nitrogen adsorption at $p / p_{0}=0.98-0.99(p$ and $p_{0}$ denote the equilibrium pressure and the saturation pressure of nitrogen at $77.4 \mathrm{~K}$, respectively). The nitrogen desorption data [25] were used to compute pore size distributions (PSDs) (differential $f_{\mathrm{v}}\left(R_{\mathrm{p}}\right) \sim \mathrm{d} V_{\mathrm{p}} / \mathrm{d} R_{\mathrm{p}}$ and $\left.f_{\mathrm{S}}\left(R_{\mathrm{p}}\right) \sim \mathrm{d} S / \mathrm{d} R_{\mathrm{p}}\right)$ using a regularization procedure [26] under non-negativity condition $\left(f_{\mathrm{V}}\left(R_{\mathrm{p}}\right) \geq 0\right.$ at any $R_{\mathrm{p}}$ ), at a fixed regularization parameter $\alpha=0.01$, with a model of voids between spherical nanoparticles packed in random aggregates (V model) with a self-consistent regularization (SCR) procedure $[27,28]$. The differential distribution functions $f_{\mathrm{V}}\left(R_{\mathrm{p}}\right)\left(\int f_{\mathrm{V}}\left(R_{\mathrm{p}}\right) d R_{\mathrm{p}} \sim V_{\mathrm{p}}\right)$ were converted to incremental PSD (IPSD, $\Phi\left(R_{\mathrm{p}}\right)$ at $\left.\sum \Phi_{i}\left(R_{\mathrm{p}}\right) \sim V_{\mathrm{p}}\right)$. Additionally, the PSD was calculated using the NLDFT method with the equilibrium model of cylindrical pores in silica (Quatachrome software).

Calculations of the specific surface area $S_{\varphi}$ (at $N=3, t$ and $r_{\mathrm{m}}$ at $\left.0.05<p / p_{0}<0.3\right)$ were carried out with equation $[24,28]$ 
$S_{\varphi}=\int_{a_{\min }}^{a_{\max }} \frac{3}{2 a^{3} \rho}\left[2(a+t)^{2}+N r_{m} \arcsin \left(\frac{a}{a+t+r_{m}}\right) \sqrt{\left(a+t+r_{m}\right)^{2}-a^{2}}-N(a+t)\left(\frac{a r_{m}}{a+t+r_{m}}+t\right)\right] \varphi(a) d a$,

where $a$ is the particle radius, $\rho$ is the silica density, $N$ is the average coordination number of primary particles in aggregates, $t$ is the thickness of an adsorbed nitrogen layer, $r_{\mathrm{m}}$ is the meniscus radius corresponding to radius of void between spherical particles, and $\varphi(a)$ is the particle size distribution calculated using the self-consistent regularization procedure for $f_{\mathrm{V}}(R)$ and $\varphi(a)$ with the model of voids between spherical nanoparticles. An additional criterion $\left|S_{\varphi}-S_{\mathrm{BET}}\right|<1 \mathrm{~m}^{2} / \mathrm{g}$ was used to determine the $a_{\min }$ and $a_{\max }$ values for the $\varphi(a)$ distributions calculated at $p / p_{0}<0.4$ without volume filling of voids [28].

\section{RESULTS AND DISCUSSION}

The primary particle size distributions of nanooxides (Fig. $1 b$ ) are in a good agreement with the average crystallite sizes, i.e. coherent-scattering region sizes (Table, $d_{\mathrm{CSR}}$ ). Some difference in the $\varphi(a)$ peak position and the $d_{\mathrm{CSR}}$ values is due to the difference in the used methods, types of particles (spherical particles for whole materials in V/SCR and only crystallites in XRD) with the presence of amorphous phase in the samples studied. The pore size distributions, PSD (Fig. $1 a$ ) show that primary particles are aggregated. Aggregates of primary particles and agglomerates of aggregates are responsible for the textural porosity of the fumed oxide powders corresponding to voids between primary particles randomly packed in secondary structures characterized by very broad PSD.

Analysis of phase composition of nanoalumina shows that $5 \%$ and $20 \%$ of amorphous component is in sa96m (composed of alumina of mainly crystalline $\theta$ phase and $4 \%$ of totally amorphous A-300) and in f140 ( $\delta$ phase), respectively. In sa96m, this is mainly due to $4 \%$ of amorphous $\mathrm{SiO}_{2}$.

Comparison of the $\mathrm{O} K_{\alpha}$ band $[29,30]$ of pure $\theta$ phase (Fig. $2 a$ ) shows that a decrease in the $d_{\mathrm{CSR}}$ values from $20 \mathrm{~nm}$ (sa96f) to $17 \mathrm{~nm}$ (f89) leads to narrowing $b$ peak in both low-energy $(h v=221.5-224.0 \mathrm{eV}$ with narrowing by $0.2-0.3 \mathrm{eV})$ and high-energy $(226.0-228.0 \mathrm{eV}$ by $0.2-0.6 \mathrm{eV}$ ) ranges. Mixed covalent-binding hybridized $\mathrm{Al} s p d+\mathrm{O} p$ and weakly-binding $\mathrm{O} p \pi$ states are represented in the first region and nonbinding states occupied by electrons transferred (during USXE spectra recording) from oxygen to aluminum atoms are located in the second region [17]. Therefore, narrowing energy distribution in the long-wave region is a consequence of disappearance of energy level splitting due to breakage of the $\sigma$ and $\pi$-type bonds with covalent components in $\mathrm{Al}-\mathrm{O}$ and $\mathrm{O}-\mathrm{O}$ interactions. The latter is due to overlapping $\mathrm{O} p$-states, since in the $\theta$-phase, the distances between oxygen atoms $r_{\mathrm{O}-\mathrm{O}}=0.2615$ and $0.2637 \mathrm{~nm}$ are shorter than double radius of oxygen ions $2 r\left(\mathrm{O}^{-2}\right)=0.266 \mathrm{~nm}$.
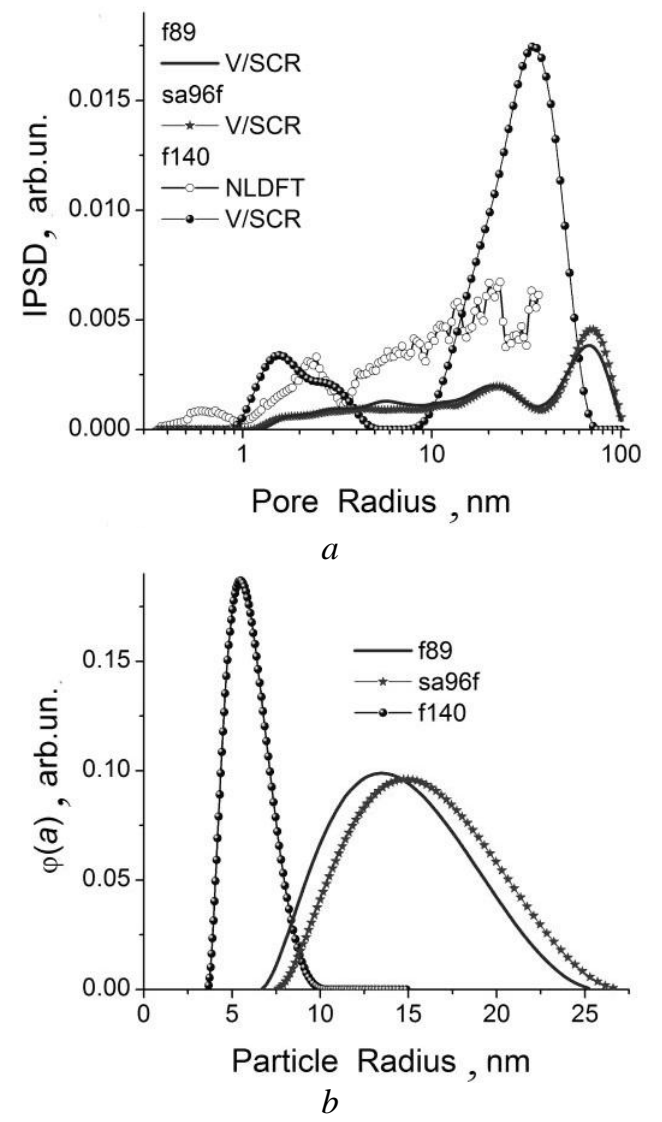

Fig. 1. Pore size distributions calculated using NLDFT (cylindrical pore model) and V/SCR method (a); primary particle size distributions for fumed oxides calculated using V/SCR method $(b)$

Electrons transferred from $\mathrm{O}$ to $\mathrm{Al}(\mathrm{Al}-\mathrm{O}$ bond breakage) occupy vacant high-energy $d$-levels that correspond to the $b$ maximum of $\mathrm{Al} L_{2,3}$ emission band [14]. Comparison of the $\mathrm{Al} L_{2,3}$ bands (Fig. $3 a$ ) of sa96m (with f89+4\% A-300, $\left.d_{\mathrm{CSR}}=11 \mathrm{~nm}\right)$ and sa96f $\left(d_{\mathrm{CSR}}=20 \mathrm{~nm}\right)$ shows that 
intensity and width of the $b$ peak are greater for sa96m than for sa96f. The spectrum of 889 $\left(d_{\mathrm{CSR}}=17 \mathrm{~nm}\right)$ is located between the spectra of sa96m and sa96f. Thus, MCA of f89+A-300 (i.e. sa96m) results in certain changes in the particle morphology and electron structure.

The energetic levels of the electronic states non-involved into covalent bonds of the $\sigma$ - and $\pi$-types do not split and concentrate near the valence band top. Therefore, a decrease in the $\mathrm{O} K_{\alpha}$ intensity in a high-energy part can represent diminution of occupation of the $\mathrm{O} p$ states that leads

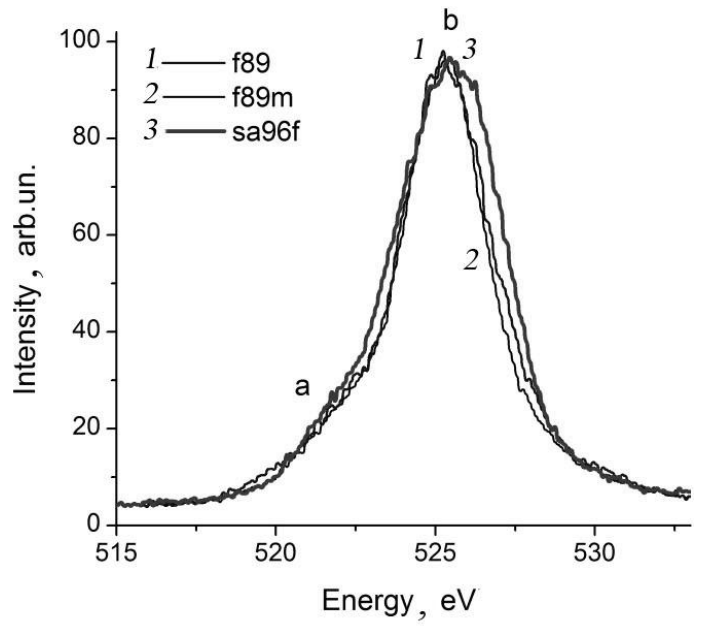

$a$ to a decrease in the negative charge (i.e. electron density) of the $\mathrm{O}$ atoms. Electrons return to $\mathrm{Al}$ atoms onto non-occupied states that adjoin to occupied states. The return of electrons to $\mathrm{Al}$ leads to an increase in intensity of the X-ray emission band in the high-energy part of the spectrum since electrons from $\mathrm{O} p$ states go to $\mathrm{Al} s$ or $\mathrm{Al} d$ states that is allowed by selection rules $|\Delta l|=1$. These states are represented by $\mathrm{Al} L_{\alpha}$ emission bands. Thus, intensity of the high-energy $b$ peak increases if the $d_{\text {CSR }}$ value decreases.

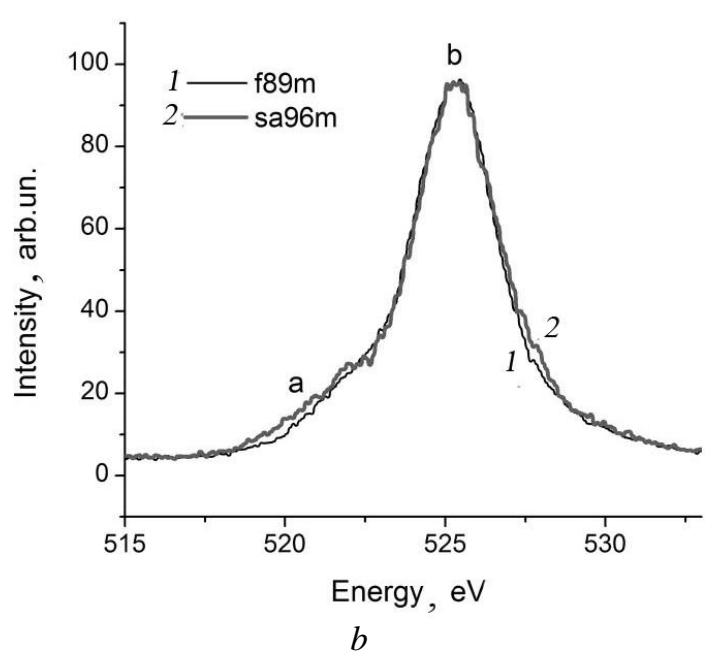

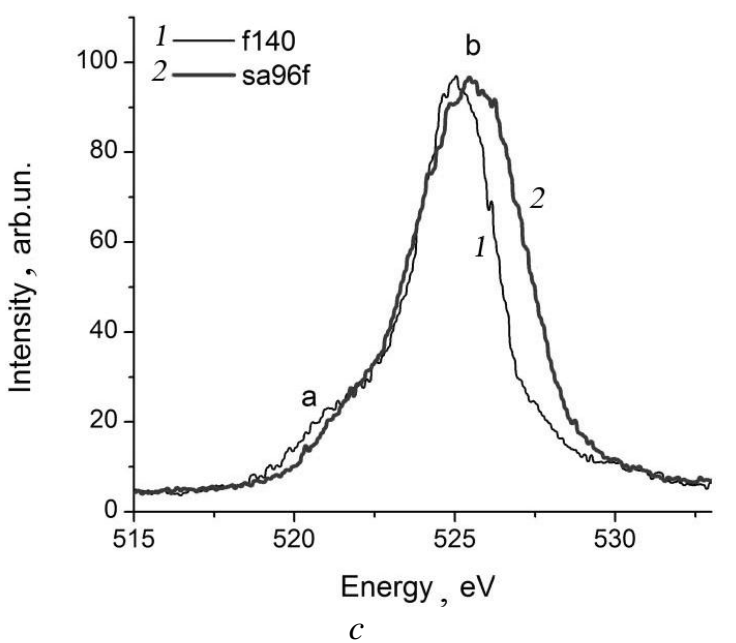

Fig. 2. The $\mathrm{O} K_{\alpha}$ emission bands of alumina ( $\theta$-phase) in samples characterized by different sizes of crystallites $(a)$ f 89 initial and MCA and sa96f; (b) MCA individual f89 (f89m) and in a mixture with A-300 (sa96m); and (c) f140 and sa96f possessing minimum $(7 \mathrm{~nm})$ and maximum $(20 \mathrm{~nm})$ sizes of crystallites

Analysis of the parameters of the X-ray emission spectra shows that diminution of sizes of alumina nanoparticles of the $\theta$-phase leads to electron return to $\mathrm{Al}$ atoms after $\mathrm{Al}-\mathrm{O}$ bond breakage. The surface energy increases during grinding crystalline particles. A high-charge state of surface $\mathrm{O}$ atoms becomes energetically unfavorable and electrons from the states with the highest energy at the top of the valence band transfer to the states located on $\mathrm{Al}$ atoms with lower energy. 
The difference in the CSR values of the $\theta$ phase in $889 \mathrm{~m}$ (MCA treated f89) and sa96m (composed of $\mathrm{f} 89+\mathrm{A}-300 \mathrm{MCA}$ treated) is small $\left(d_{\mathrm{CRS}}=13\right.$ and $11 \mathrm{~nm}$, respectively). Comparison of the USXES bands of these samples elucidates the influence of amorphous components on the $\mathrm{O} K_{\alpha}$ spectra. The $\mathrm{O} K_{\alpha}$ bands of $\mathrm{f} 89 \mathrm{~m}$ and sa96m samples are almost coincident (Fig. $2 b$ ) since they are MCA prepared using the same alumina f89. The difference between these bands is the splitting of low-energy sub-band $a$ due to presence of $4 \%$ admixture of $\mathrm{SiO}_{2}$ in sa96m since the low-energy maximum $a$ in the $\mathrm{O} K_{\alpha}$ band of silica is separated from the main $b$ peak of alumina. Somewhat higher intensity of spectrum of sa96m in comparison with f89m is observed in the $h v=226.5-228.5 \mathrm{eV}$ region. This is a consequence of overlapping $\mathrm{O} K_{\alpha}$ spectra of alumina and silica in sa96m.
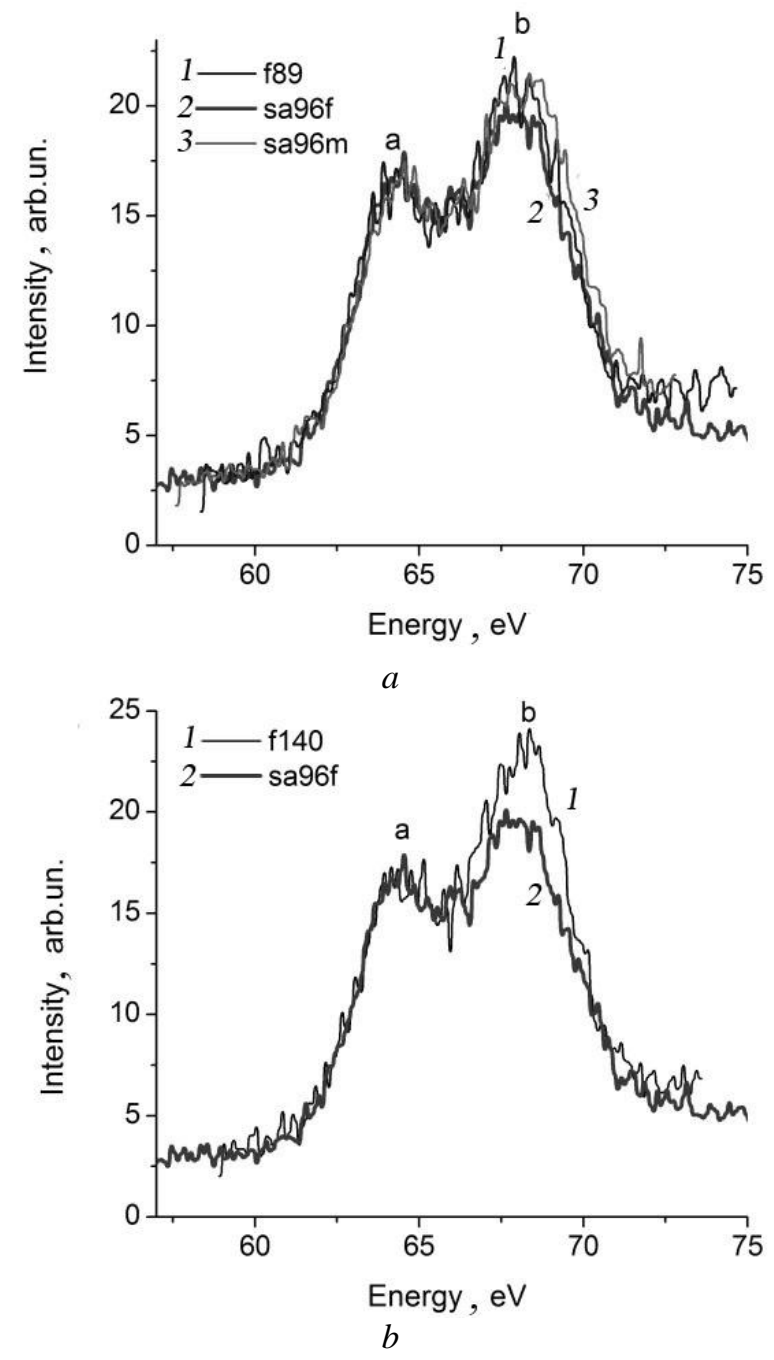

Fig. 3. X-ray emission $\mathrm{Al} L_{2,3}$ spectra of (a) f89, sa96f and sa96m; and $(b)$ f140 and sa96f
The narrowest $b$ maximum is observed in the $\mathrm{O} K_{\alpha}$ band of the $\delta$ phase of $\mathrm{f} 140$ at $d_{\mathrm{CSR}}=7 \mathrm{~nm}$ (fumed alumina at $S_{\mathrm{BET}}=140 \mathrm{~m}^{2} / \mathrm{g}$ ) (Fig. 2 c). Narrowing of this band in the high-energy part by $1.2 \mathrm{eV}$ is due to a shift of the short-wave contour of the $b$ peak towards lower energy that is well seen in comparison with the spectrum of $\theta-\mathrm{Al}_{2} \mathrm{O}_{3}$ in sa96f at $d_{\mathrm{CSR}}=20 \mathrm{~nm}$. However, in contrast to the $\theta$ phase intensity of the $a$ maximum representing covalent binding $\mathrm{O} p+\mathrm{Al} s d$ states is slightly greater. This narrowing of the $\mathrm{O} K_{\alpha}$ band in the short-wave part of the $b$ peak occurs due to return of electrons to $\mathrm{Al}$ ions after the $\mathrm{Al}-\mathrm{O}$ bond breakage that is confirmed by a greater increase in relative intensity of the $b$ peak (Fig. $3 b$ ) in the $\mathrm{Al}_{2,3}$ band in comparison of $\delta-\mathrm{Al}_{2} \mathrm{O}_{3}$ at $d_{\mathrm{CSR}}=7 \mathrm{~nm}$ with $\theta-\mathrm{Al}_{2} \mathrm{O}_{3}$ at $d_{\mathrm{CSR}}=20 \mathrm{~nm}$. This difference is much greater than that for sa96f and sa96m samples (Fig. $3 a$ ).

The peak shift of the $\mathrm{O} K_{\alpha}$ band toward lower energy for the $\delta$ phase $\left(d_{\mathrm{CSR}}=7 \mathrm{~nm}\right)$ is due to overlapping of the $\mathrm{O} p$ orbitals under higher Laplace pressure in smaller nanoparticles in which stronger $\mathrm{O}-\mathrm{O}$ interactions are due to shorter distances between the $\mathrm{O}$ atoms $(0.2295-0.2618 \mathrm{~nm})$ [23]. These distances are shorter than double radius of oxygen ions $(0.266 \mathrm{~nm})$ in the alumina lattice. Tightening forces that appear as a result of these $\mathrm{O}-\mathrm{O}$ interactions cause a decrease in the $\mathrm{Al}-\mathrm{O}$ distances in the volume of the $\delta$ phase, most of which are in the $0.1718-0.1805 \mathrm{~nm}$ range in comparison with the bond length in the $\theta$-phase, among which only about $15 \%$ of the Al-O distances are equal to $0.171 \mathrm{~nm}$.

The decrease in the Al-O distances in the $\delta$ phase leads to increasing overlapping of $\mathrm{Al} s d+\mathrm{O} p$ covalent-binding states reflecting in the shift of long-wave contour of sub-band $a$ by $0.2-0.5 \mathrm{eV}$ toward lower energy. This indicates the strengthening of the $\mathrm{Al}-\mathrm{O}$ bonds accompanied by stronger $\mathrm{O}-\mathrm{O}$ interactions in the lattice and stabilization of the $\delta$ phase in nanosized alumina particles at $d_{\mathrm{CSR}}=7 \mathrm{~nm}$ which is smaller than that in the $\theta$ phase $(11-20 \mathrm{~nm})$ of nanoaluminas studied.

\section{CONCLUSION}

A decrease in sizes of alumina nanoparticles and an increase in contribution of surface atoms lead to a decrease in oxygen charging due to return of the electron density to Al cations in the surface layer of smaller nanoparticles $<20 \mathrm{~nm}$ in size. The surface Al-O bonds can also break due to electron transfer under USXES measurements. The $\delta$ phase 
with strengthened Al-O bonds of enhanced covalent type stabilizes with enhancement of the $\mathrm{O}-\mathrm{O}$ interactions as a result of Laplace pressure in small nanoparticles $(<10 \mathrm{~nm})$ of fumed alumina with the specific surface area of $140 \mathrm{~m}^{2} / \mathrm{g}$ and coherent-scattering region size of $7 \mathrm{~nm}$. Thus, nanoaluminas with primary particle sizes of $15-20$ and 5-10 $\mathrm{nm}$ can have different properties because of stabilization of different crystalline phases that depend strongly on the particle sizes.

\title{
Морфологічні та електронні характеристики нанорозмірного оксиду алюмінію, індивідуального та у високотемпературних (пірогенних) і низькотемпературних (механічних) сумішах 3 нанорозмірним кремнеземом
}

\author{
Я.В. Зауличний, В.Я. Ільків, В.І. Зарко, М.В. Карпець, \\ М.В. Перегіньяк, С.С. Петровська, В.М. Гунько \\ Наиіональний ТехнічнийУніверситет «Київський Політехнічний Інститут» \\ вул. Політехнічна, 35, Київ, 03056, Украӥна \\ Інститут хімії поверхні ім. О.О. Чуйка Національної академї̈ наук Украйни \\ вул. Генерала Наумова, 17, Київ, 03164, Україна, vlad_gunko@ukr.net \\ Інститут проблем матеріалознавства ім. І.М. Франщевича Начіональної академії наук Украӥни \\ вул. Крижижановського, 3, Київ, 03680, Україна \\ Методами рентгенівської дифракції та ультрам'якої рентгенівської емісійної спектроскопї \\ проаналізовано кристалічну будову та електронну структуру нанорозмірного оксиду алюмінію в \\ різних змішаних системах з нанорозмірним кремнеземом. Звуження смуг ОК $а$ в кристалічному \\ оксиді алюмінію симбатно зміні розміру наночастинок $\mathrm{Al}_{2} \mathrm{O}_{3}$. Перенесення електронів від атомів \\ кисню на вільні 3d-рівні атомів алюмінію відбувається внаслідок розриву зв'язку Al-O при діі \\ електронного пучка на $\mathrm{Al}_{2} \mathrm{O}_{3}$. В наночастинках, де зв'язки Al-O міџні $i$ взаємодії між $\mathrm{O}-\mathrm{O}$ \\ підсилені за рахунок лапласівського тиску, відбувається стабілізація $\delta$ фази оксиду алюмінію, \\ якщь розмір когерентно-розсіючої області $\left(d_{C S R}\right)$ не перевищує 7 нм, тобто менше, ніж для $\theta$-фази \\ оксиду алюмінію $\left(d_{C S R}=11-20\right.$ нм) та алюмокремнезему.
}

Ключові слова: нанооксид алюмінію, нанокремнезем, електронна структура, ультрам'яка рентгенівська спектроскопія, рентгенівська дифракиія

\section{Морфологические и электронные характеристики наноразмерного оксида алюминия, индивидуального и в высокотемпературных (пирогенных) и низкотемпературных (механических) смесях с наноразмерным кремнеземом}

\author{
Я.В. Зауличный, В.Я. Илькив, В.И. Зарко, М.В. Карпец, \\ М.В. Перегиньяк, С.С. Петровская, В.М. Гунько
}

Национальный Технический Университет «Киевский Политехнический Институт» ул. Политехническая, 35, Киев, 03056, Украина

Институт химии поверхности им. А.А. Чуйко Национальной академии наук Украиньл

ул. Генерала Наумова, 17, Киев, 03164, Украина, vlad_gunko@ukr.net

Институт проблем материаловедения им. И.Н. Франџевича Национальной академии наук Украинь ул. Крижсисановского, 3, Киев, 03680, Украина

\footnotetext{
Методами рентгеновской дифракиии и ультрамягкой рентгеновской эмиссионной спектроскопии проанализированы кристаллическое строение и электронная структура наноразмерного оксида алюминия в различных смешанных системах с наноразмерным кремнеземом. Сужение полос $O_{\alpha}$ в кристаллическом оксиде алюминия симбатно изменению
} 
размера наночастии $\mathrm{Al}_{2} \mathrm{O}_{3}$. Перенос электронов от атомов кислорода к атомам алюминия на свободные 3d-уровни происходит вследствие разрыва связи Al-O при воздействии электронного пучка на $\mathrm{Al}_{2} \mathrm{O}_{3}$. В наночастицах, где связи $\mathrm{Al}-\mathrm{O}$ прочны и взаимодействия между $\mathrm{O}-\mathrm{O}$ усилены за счет лапласовского давления, происходит стабилизация $\delta$ фазы оксида алюминия, если размер когерентно-рассеивающей области $\left(d_{C S R}\right)$ не превышает 7 нм, т.е. меньше, чем для $\theta$-фазы оксида алюминия $\left(d_{C S R}=11-20\right.$ нм) и алюмокремнезема.

Ключевые слова: нанооксид алюминия, нанокремнезем, электронная структура, ультрамягкая рентгеновская спектроскопия, рентгеновская дифракиия

\section{REFERENCES}

1. Fendler J.H. (Ed.) Nanoparticles and Nanostructured Films, Weinheim, Wiley$\mathrm{VCH}, 1998,490 \mathrm{p}$.

2. Iler R.K. The Chemistry of Silica, Wiley, Chichester, 1979, $886 \mathrm{p}$.

3. Swihart M.T. Vapor-phase synthesis of nanoparticles. Current Opinion Colloid Interface Sci. 8 (2003) 127.

4. Blitz J.P., Gun'ko V.M. (Eds.) Surface Chemistry in Biomedical and Environmental Science, Springer, Dordrecht, NATO Science Series II: Mathematics, Physics and Chemistry, 2006, $434 \mathrm{p}$.

5. Hubbard A.T. (Ed.) Encyclopedia of Surface and Colloid Science, New York, Marcel Dekker, 2002, 5667 p.

6. Bergna H.E. (Ed.) Colloidal Silica: Fundamentals and Applications, Salisbury, Taylor \& Francis LLC, 2005, 953 p.

7. Shpak A.P., Gorbik P.P. (Eds.) Nanomaterials and Supramolecular Structures: Physics, Chemistry and Applications, Springer, Dordrecht, 2010, 420 p.

8. Inorganic Materials for Catalyst Innovation AEROSIL $®, \quad$ AEROXIDE $®$ and SIPERNAT ${ }^{\circledR}$ Metal Oxides and Silica Based Materials, Industry Information 2242, Evonik Ind. (Germany), http://www.sipernat.com/sites /dc/Downloadcenter/Evonik/Product/SIPERN

AT/11-01-344-vnd-ii-2242-katalysatorenus.pdf.

9. Sposito G. (Ed.) The Environmental Chemistry of Aluminum, Boca Raton: Second edition, Lewis Publishers, 2000, 271.

10. Lin C., Chung D.D.L. Nanostructured fumed metal oxides for thermal interface pastes. J. Mater. Sci., 42 (2007) 9245.

11. Zaulychnyy Ya.V., Foya O.O., Bekeniov V.L. et al. Energy redistribution of valence electrons in anatase $\mathrm{TiO}_{2}$ due to decreasing nanoparticles sizes. Nanostructured Materials Science, 2 (2009) 103.

12. Gun'ko V.M., Zaulychnyy Ya.V., Ilkiv B.I. et al. Textural and electronic characteristics of mechanochemically activated composites with nanosilica and activated carbon. Applied Surface Science, 258 (2011) 1115.

13. Zaulychnyy Ya.V., Solonin Yu.M., Foya O.O. et al. Energy redistribution of the valence electrons due to nanodispersion of materials and its evidence as determined by the ultrasoft X-ray emission spectra. Metallofiz. Noveishie Teknol, 30 (2008) 169 (in Russian).

14. Zatsepin D.A., Cherkashenko V.M., Kurmaev E.Z. et al. X-ray emission study of the electronic structure of nanocrystaline $\mathrm{Al}_{2} \mathrm{O}_{3}$. Physics of the Solid State, 46 (2004) 2064 (in Russian).

15. Toporov N.A., Barzakovskij V.P., Bondar I.A., Udalov Yu.P. Phase Diagrams of Silicate Systems, Leningrad, Nauka, 1970, 278 p. (in Russian).

16. Ishida Y., Ichinose H., Kizuka T., Suenaga K. High-resolution electron microscopy of interfaces in nanocrystalline materials. Nanostruct. Materials, 6 (1995) 115.

17. Zaulychnyy Ya.V., Foya O.O., Gun'ko V.M. et $a l$. The influence of nanoparticle size of fumed silica on energetic state of valence electrons. Physics and Chemistry of Solids, 4 (2008) 767.

18. Domashevskaya E.P., Yurakov Yu.A., Bodnar D.M., Kashkarov V.M.. XPS, USXS and PLS investigations of porous silicon. J. Electron Spectrosc. Relat. Phenom., 88 (1998) 963.

19. Domashevskaya E.P., Kashkarov V.M., Manukovskii E.Yu. et al. Specific features of electron structures of some thin film $d$-silicides. J. Electron Spectrosc. Relat. Phenom., 88 (1998) 969.

20. Katayama T., Anniyev T., Beye M. et al. Ultrafast soft X-ray emission spectroscopy of surface adsorbates using an X-ray free electron 
laser. J. Electron Spectrosc. Relat. Phenom., 187 (2013) 9.

21. Nordgren J., Guo J. Soft-X-ray spectroscopy study of nanoscale materials. J. Electron Spectrosc. Relat. Phenom., 110 (2000) 1.

22. Terekhov V.A., Kashkarov V.M., Manukovskii E.Yu. et al. Determination of the phase composition of surface layers of porous silicon by ultrasoft X-ray spectroscopy and X-ray photoelectron spectroscopy techniques. J. Electron Spectrosc. Relat. Phenom., 114 (2001) 895.

23. Dollase W.A. Correction of intensities for preferred orientation in powder diffractometry: application of the March model. J. Appl. Cryst., 19 (1986) 267.

24. Gregg S.J., Sing K.S.W. Adsorption, Surface Area and Porosity, London, Academic Press, 1982, $303 \mathrm{p}$.

25. Nguyen C., Do D.D. a new method for the characterization of porous materials. Langmuir, 15 (1999) 3608.
26. Provencher S.W. Constrained regularization method for inverting data. Comp. Phys. Comm. 27 (1982) 213.

27. Gun'ko V.M., Bogatyrev V.M., Leboda R. et al. Titania deposits on nanosilicas. Annales Universitatis Marie Curie-Sklodowska, Sectio Chemia. 64 (2009) 21.

28. Gun'ko V.M., Turov V.V. Nuclear Magnetic Resonance Studies of Interfacial Phenomena, Boca Raton, CRC Press, 2013, 1072 p.

29. Romashchenko Yu.N. X-ray spectral investigation of electronic structure of oxoanions of aluminum and silica in oxides and minerals, Thesis abstract, Rostov-on-Don, 1978 (in Russian).

30. Brytov A.A., Romashchenko Yu.N. X-ray spectroscopic investigation of the electronic structure of silicon and aluminium oxides. Sov. Phys. Solid State, 20 (1978) 384 (in Russian).

Received 14.11.2013, accepted 02.04.2014 